\title{
EFISIENSI APARATUR DESA DALAM PENYELENGGARAAN \\ PEMERINTAHAN DESA (DI DESA HENDA KECAMATAN JABIREN RAYA KABUPATEN PULANG PISAU)
}

\author{
Betty Karya \\ Fakultas IImu Sosial dan IImu Politik Universitas PGRI Palangka Raya \\ (email: betykarya@gmail.com)
}

\begin{abstract}
Abstrak
Tujuan penelitian sebagai berikut Untuk mendeskripsi dan menganalisis Kompetensi Aparatur Desa tentang Penyelenggaraan Pemerintahan Desa Henda,Untuk mendeskripsi dan menganalisis faktor yang mempengaruhi Kompetensi dari Aparatur Desa Henda.

Metode yang digunakan adalah penelitian kualitatif adapaun teknik pengumpulan data yang digunakan yaitu Observasi, Wawancara dan Dokumentasi. Berdasarkan hasil penelitian Kompetensi Aparatur Desa dalam Penyelenggaraan Pemerintahan Desa di Desa Henda Kecamatan Jabiren Raya Kabupaten Pulang Pisau.

Kesimpulanpe nelitian sebagai berikut: Aparatur Desa adalah Pemerintah Desa dan Badan Permusyawaratan Desa yang dapat dikatakan sebagai ujung tombak sebagai pelaksana penyelenggaraan Penyelenggaraan Pemerintahan Desa, Kompetensi dari Aparatur Desa di Desa Henda sudah cukup baik karena dalam penyelenggaraan Pemerintahan Desa Aparatur Desa Henda selalu berpegang dan memperhatikan asasasas penyelenggaraan Pemerintahan Desa. Aparatur Desa Henda juga dalam menyelenggarakan Pemerintahan Desa dilaksanakan atas dasar musyawarah desa dimana musyawarah desa adalah hasil keputusan tertinggi yang ada didesa sesuai dengan amanat Undang-Undang. Dalam melakukan penyelenggaraan Pemerintahan Desa Aparatur Desa sudah profesional dikarenakan apabila Aparatur Desa mendapatkan suatu ransangan atau masalah dari luar tidak pernah berimbas pada pekerjaan yang lainnya.

Dalam pelaksanaan penyelenggaraan Pemerintahan Desa di Desa Henda terjadinya Kurangnya kordinasi dari Aparatur Desa (Pemerintah Desa dan Badan Permusyawaratan Desa) mengakibatkan pengembangan Kompetensi lemahnya kepada satu pihak dan akan menguat pengembangan Kompetensi kepada satu pihak. Motivasi Kerja dari Aparatur Desa terutama Badan Permusyarawatan Desa (BPD) yang sebagai mitra kerja dari Pemerintah Desa menurun dikarenakan belum terpenuhinya kebutuhan operasional karena sebenarnya mengikuti seiring dengan apa yang direncanakan.
\end{abstract}


Apabila berbicara masalah motivasi berarti akan bersamaan membahas Kompetensi karena variabel yang sangat berpengaruh bagi Kompetensi ialah motivasi.

\section{Kata Kunci: Efisiensi Aparatur Desa}

\section{Pendahuluan}

Indonesia merupakan Negara yang menggunakan konsep welfare state dalam menjalankan pemerintahannya dengan tujuan untuk menciptakan kesejahteraan sosial bagi seluruh rakyat Indonesia. Welfare State, secara singkat dapatdiartikan sebagai serangkaian kebijakan publik dan kegiatan Negara dalam mengintegrasikan kebijakan ekonomi dan kebijakan sosial demi sebuah pencapaian kemakmuran.

Serangkaian kebijakan yang diwujudkan dalam suatu kegiatan dilakukan dalam menjalankan pemerintahan, salah satunya yaitu dengan membuat suatu kebijakan yang akan mempermudah dalam melaksanakan rancangan program pembangunan Nasional. Pembangunan Nasional dan daerah merupakan bagian yang tidak dapat dipisahkan dari kegiatan pembangunan desa. Desa merupakan basis kekuatan sosial ekonomi dan politik yang perlu mendapat perhatian serius dari pemerintah. Perencanaan pembangunan selama ini hanya menjadikan masyarakat desa sebagai objek pembangunan bukan sebagai subjek pembangunan. Sistem Pemerintahan Negara Kesatuan Republik Indonesia menurut Undang-Undang Dasar 1945 memberikan keleluasaan kepada daerah untuk menyelenggarakan otonomi daerah. Dalam penyelenggaraan otonomi daerah, dipandang perlu untuk menekankan pada prinsip-prinsip demokrasi, peran serta masyarakat, pemerataan dan keadilan serta memperhatikan potensi dan keanegaraman daerah. apabila pegawainya memiliki pengetahuan, keterampilan, dan sikap perilaku yang dibutuhkan dalam menjalankan tugas dan fungsinya. Masalah yang dihadapi pemerintah saat ini adalah keterbatasan memiliki sumber daya yang berkualitas, ini menjadi suatu fenomena yang sekaligus menjadi masalah utama yangdihadapi dalam penyelenggaraan pemerintahan desa diberbagai daerah di Indonesia. Aparatur desa adalah semua unsur yang mempunyai peran penting dan yang terlibat sebagai penyelenggara pemerintahan desa seperti, Kepala Desa, BPD, Sekretaris Desa, Kaur, Karang Taruna dan kelembagaan desa yang terkait.

Maka dari hal tersebut Kompetensi dari Aparatur Desa di Desa Henda merupakan sesuatu yang penting untuk dibahas. Dalam penyelenggaraan pemerintahan desa terutama dalam lingkup pembangunan desa sangat dibutuhkan suatu kompetensi Aparatur Desa yang mumpuni dengan tujuan agar pembangunandapat berjalan efektif sesuai dengan ketentuan yang berlaku.

\section{Otonomi Desa}

Secara etimilogi kata desa berasal dari bahasa sangsekerta, deca yang berarti tanah air, tanah asal, atau tanah kelahiran. Dari perspektif georafis, desa atau village diartikan sebagai "a groups of houses or shops in country area, smaller than a town". Desa adalah kesatuan masyarakat hukum yang memiliki kewenangan mengurus rumah tangganya sendiri 
berdasarkan hak asal usul dan adat istiadat yang diakui oleh Pemerintahan Nasiolan dan berada di Daerah Kabupaten.

Bagi masyarakat desa, otonomi desa bukanlah merujuk pada otonomi Pemerintah Desa semata-mata tetapi otonomi masyarakat desa dalam menemukan diri mereka dan mengelola apa yang mereka miliki untuk kesejahteraan mereka sendiri. Otonomi desa berarti juga memberikan ruang yang jelas bagi inisiatif dari desa. Kebebasan untuk menentukan dirinya sendiri dan keterlibatan masyarakat dalam semua proses baik dalam pengambilan keputusan berkala desa, perencanaan dan pelaksanaan pembangunan maupun kegiatan-kegiatan lain yang dampaknya akan dirasakan oleh masyarakat desa sendiri.

Keberadaan otonomi desa mengacu pada konsep komunitas, yang tidak hanya dipandang sebagai unit wilayah, tetapi juga sebagai sebuah kelompok sosial, sebagai suatu sistem sosial, maupun sebagai kerangka kerja interaksi. Otonomi desa merupakan hak, wewenang dan kewajiban untuk mengatur dan mengurus sendiri urusan pemerintahan dan kepentingan masyarakat berdasarkan hak asal-usul dan berdasarkan nilai-nilai sosial yang ada pada masyarakat untuk tumbuh dan berkembang mengikuti perkembangan desa tersebut.

Dalam Undang-Undang Nomor 6 tahun 2014 tentang desa berpendapat bahwa desa adalah desa dan desa adat atau yang disebut dengan nama lain, selanjutnya disebut Desa, adalah kesatuan masyarakat hukum yang memiliki batas wilayah yang berwenang untuk mengatur dan mengurus urusan pemerintahan, kepentingan masyarakat, setempat berdasarkan prakarsa masyarakat, hak asal usul dan/ atau hak tradisional yang diakui dan dihormati dalam sistem pemerintahan Negara Kesatuan Republik Indonesia.

Tujuan pembentukan desa adalah meningkatkan

kemampuan

penyelenggaraan pemerintahan secara berdaya guna dan berhasil guna dan peningkatan pelayanan terhadap masyarakat sesuai dengan tingkat perkembangan dan kemajuan pembangunan. Dalam menciptakan pembangunan hingga di tingkat akar rumput maka maka terdapat beberapa syarat yang harus dipenuhi untuk pembentukan desa yakni: Pertama, faktor penduduk minimal 2500 jiwa atau 500 kepala keluarga, Kedua, faktor luas yang terjangkau dalam pelayanan dan pembinaan masyarakat, Ketiga, faktor letakyang memiliki jaringan perhubungan atau komunikasi antar dusun, Keempat, faktor sarana prasarana, tersedianya sarana perhubungan, pemasaran, sosial, produksi, dana sarana pemerintah desa, Kelima, faktor sosial budaya, adanya kerukunan hidup beragama dan kehidupan bermasyarakat dalam hubungan adat istiadat, Keenam, faktor kehidupan masyarakat yaitu tempat untuk keperluan mata pencaharian masyarakat.

\section{Jurnal Sociopolitico}




\section{Penyelenggaraan Pemerintahan Desa}

\section{Pemerintah Desa}

Dalam Undang-Undang No 6 Tahun 2014 tentang desa ( pasal 1 ayat 3 dan 4) menyatakan bahwa Pemerintah Desa ialah Kepala Desa atau yang disebut dengan nama lain dibantu oleh perangkat desa sebagai unsur penyelenggaraan pemerintahan desa. Badan Permusyawaratan Desa atau yang disebut dengan nama lain adalah lembaga yang melaksanakan fungsi pemerintahan yang anggotanya merupakan wakil dari penduduk desa berdasarkan keterwakilan wilayah dan ditetapkan secara demokratis.

Pemerintah (goverment) secara etismilogis, berasal dari bahasa Yunani Kuno yauitu "kubernan" atau sebagai nahkoda kapal. Artinya menatap ke depan lalu, perkataan "memerintah" berarti melihat ke depan, menentukan berbagai kebijakan diselenggarakan untuk mencapai tujuan masyarakat atau negara, memperkirakan arah perkembangan masyarakat masa mendatang dan mempersiapkan langkah-langkah kebijakan untuk menyonsong perkembangan masyarakat serta mengelola dan mengarahkan masyarakat kepada tujuan yang telah ditetapkan (Sitepu, $2012: 147$ ).

Para ahli mendefinisikan desa sebagai berikut :

Bintaro (1968 : 95 ) berpendapat bahwa desa merupakan suatu perwujudan geografi yang ditimbulkan oleh unsur-unsur fisiogrfis sosial ekonomis, politis, dan cultural yang terdapat di situ dalam hubungan hubungan dan pengaruh timbal balik dengan daerah-daerah lain. Sedanngkan Beratha (1982 : 27) bahwa desa atau

kebijakan pembenahan sistem pemerintahan sesuai dengan kondisi sosial buadaya dan aspirasi masyarakat desa tersebut.

Kelahiran Undang-Undang No 6 Tahun 2014 tentang Desa disambut semarak, tidak terbatas oleh pemerintah desa. Undang-Undang desa menjadi topik perbincangan diberbagai diskusi publik, media, maupun keseharian warga. Optimisme tumbuh mesti tidak semua pihak menatap Undang-Undang No 6 Tahun 2014 tentang Desa dengan pemahaman yang sama. Sebagian melihatnya sebagai tonggaknya dimulainya pendalaman demokrasi pada asas lokal, lainnya menganggap Undang-Undang desa sebagai jalan membangun kemandirian desa ekonominnya.

Dalam sejarah pengaturan desa, telah ditetapkan beberapa peraturan tentang desa, yaitu Undang-Undang Nomor 22 tahun 1948 tentang tentang pokok pemerintahan daerah, Undang-Undang Nomor 18 tahun 1965 tentang desa sebagai bentuk peralihan untuk mempercepat terwujudnya daerah tingkat III diseluruh wilayah Republik Indonesia, Undang-Undang Nomor 5 tahun 1974 tentang pokok-pokok pemerintahan di daerah, Undang-Undang Nomor 22 tahun 1999 tentang pemerintahan daerah, dan terakhir dengan Undang-Undang nomor 32 tahun 2004 tentang pemerintahann daerah.

Penyelenggaraan pemerintahan desa yang memasuki babak baru ini diiringi dengan terbitkannya Undang-Undang

\section{Jurnal Sociopolitico}


Nomor 6 tahun 2014 tentang desa ini, jika kita tahu sepanjang era reformasi, pengaturan mengernai desa masuk dalam

Dengan kata lain, kemapuan adalah wujud atau akumulasi dari pengetahuan, keterampilan, dan sikap seseorang terkait dengan pekerjaan yang diembannya.

\section{Faktor-Faktor Mempengaruhi Kompetensi}

Faktor yang mempengaruhi kompetensi individu sesunggunya adalah karakteristik individu yang bersangkutan. Karakteristik pribadi ini merupakan sifatsifat atau ciri-siri yang dimiliki sesorang yang berhubungan dengan semua aspek kehidupan dan lingkungannya.

Nurius (2008) dan Marius (2007) menunjukan bahwa motivasi adalah variabel yang berpengaruh terhadap kompetensi. Rekomendasi adalah untuk meningkatkan kompetensi, motivasi individu perlu ditingkatkan agar kompetensinya juga bisa meningkat. Oleh karena itu untuk meningkatkan kompetensi, faktor-faktor yang dapat meningkatkan motivasi tersebut perlu ditingkatkan.

Motivasi memiliki peran yang penting dalam pengembangan kompetensi. Teori motivasi kerja Herzberg (Pace dan Faules, 1993) menegaskan dua hal yang memuaskan kebutuhan manusia, yaitu sebagai berikut :

1. Kebutuhan yang berkaitan dengan kepuasan kerja seperti prestasi, penghargaan, tanggungjawab, kemajuan/promorsi, pekerjaan itu sendiri, dan potensi bagi pertumbuhan pribadi.
2. Kebutuhan yang berkaitan dengan ketidakpuasan kerja seperti gaji, pengawasan, keamanan kerja, kondisi kerja, administrasi, kebijakan organisasi, hubungan antara pribadi baik atasan, rekan kerja, maupun bawahan.

Uraian diatas menunjukan bahwa asumsi tentang ciri-ciri yang mencerminkan karakteristik individu dapat berbeda-beda, tergantung pada

\section{Metode Penelitian}

Data penelitian yang digunakan oleh peneliti untuk mempertanggungjawabkan penyusunan proposal skripsi ini, penelitian menggunakan metode penelitian yang merupakan jenis penelitian kualitatif. Seperti yang dikemukakan oleh Djam'an Satori dan Aan Komariah( 2010 : 25 ), penelitian kualitatif adalah suatu pendekatan penelitian yang mengungkap situasi sosial tertentu dengan mendeskripsikan kenyataan secara benar, dibentuk oleh kata-kata berdasarkan teknik pengumpulan dan analisis data yang relevan yang diperoleh dari situasi yang alamiah. Suatu penelitian kualitatif dieksplorasi dan diperdalam dari suatu fenomena sosial atau suatu lingkungan sosial yang terdiri atas pelaku, kejadian, tempat dan waktu. Penelitian kualitatif juga seringkali digunakan untuk maksud merevisi dan transformasi sejarah, mengurangi ketidaktahuan akan sejarah, termasuk juga pengalaman dari kelompok etnik, dan ras, tingkatan sosial serta gender.

Menurut Denzin dan Lincoln dalam Djam'an Satori dan Aan Komariah (2010 : 23), penelitian kualitatif merupakan penelitian yang menggunakan latar alamiah, dengan maksud menafsirkan

\section{Jurnal Sociopolitico}


fenomena yang terjadi dan dilakukan dengan jalan melibatkan berbagai metode yang ada dengan berbagai karakteristik khas yang dimiliki, penelitian kualitatif memiliki keunikan tersendiri sehingga berbeda dengan penelitian kuantitatif. Adapun ciri-ciri pokok pada jenis penelitian kualitatif yaitu :

1. Memusatkan perhatian pada permasalahan yang ada pada saat penelitian dilakukan atau permasalahan yang bersifat aktual.

2. Menggambarkan fakta tentang permasalahan yang diselidiki sebagaimana adanya, diiringi dengan interpretasi rasional yang seimbang.

3. Pekerjaan penelitian bukan saja memberikan gambaran tentang fenomena-fenomena, tetapi juga menerangkan hubungan, menguji hipotesis, membuat prediksi, serta mendapatkan makna dan implikasi dari suatu masalah yang ada sehingga hasil penelitian bersifat fakta.

\section{Hasil dan Pembahasan}

\section{A. Kompetensi Aparatur Desa dalam Penyelenggaraan Pemerintahan Desa di Desa Henda.}

Konsep aparatur sering disandingkan dengan dua kata yaitu Negara dan Pemerintah, Aparatur Negara merupakan alat kelengkapan negara yang bekerja untuk kepentingan negara, hal ini dapat dilihat dari pengertian negara yaitu dapat diartikan sebagai organisasi yang terdiri dari sekumpulan orang yang menempati wilayah tertentu yang pengelolaannya dijalankan oleh pemerintahan yang berdaulat. Sedangkan aparatur pemerintah adalah alat negara yang bertanggung jawab untuk menjalankan roda pemerintahan.

Era reformasi membawa perubahan dalam sistem pemerintahan tingkat pusat sampai ke desa. Perubahan di tingkat desa diantaranya adanya otonomi desa. Otonomi desa berarti desa memiliki kewenangan untuk mengatur dan mengurus kepentingan masyarakatnya, ini adalah salah satu langkah untuk tercapainya penyelenggaraan pemerintahan desa yang sesuai dengan ketentuan yang berlaku. Desa merupakan penyelenggaraan pemerintahan terkecil namun merupakan unit terdepan atau sebagai ujung tombak dalam pelayanan kepada masyarakat. Karena itu Kompetensi dari Aparatur Desa yang baik merupakan salah satu langkah untuk mempercepat terwujudnya masyarakat sebagai tujuan dari otonomi desa.

Dalam

Penyelenggaraan

Pemerintahan Desa terdapat asas-asas yang harus diperhatikan, baik oleh pemerintah maupun oleh masyarakat desa. Hal ini bertujuan agar penyelenggaraan Pemerintahan Desa tidak melenceng dari aturan yang ada. Berdasarkan Pasal 24 Undang-Undang Nomor 6 Tahun 2014 Tentang Desa, penyelenggaraan Pemerintahan Desa harus memperhatikan asas-asas sebagai berikut :

1. Kepastian Hukum, Kepastian Hukum adalah asas dalam negara hukum yang mengutamakan landasan peraturan perundang-undangan, kepatutan, dan keadilan dalam setiap kebijakan penyelenggaraan Pemerintahan Desa.

2. Tertib Penyelenggaraan Pemerintahan, Tertib dalam penyelenggaran Pemerintahan adalah asas yang menjadi lansasan keteraturan, keserasian, dan keseimbangan dalam pengendalian penyelenggaraan Pemerintahan Desa.

\section{Jurnal Sociopolitico}


3. Tertib Kepentingan Umum, Tertib Kepentingan Umum adalah asas yang mendahulukan kesejahteraan umum dengan cara aspiratif, akomodatif, selektif.

4. Keterbukaan, Keterbukaan adalah asas yang membuka diri terhadap hak masyarakat untuk memperoleh informasi yang benar, jujur, dan tidak diskriminatif tentang penyelenggaraan Pemerintahan Desa dengan tetap memperhatikan ketentuan peraturan perundangundangan.

5. Proporsionalitas, Proporsionalitas adalah asas yang mengutamakan kesemimbangan antara hak dan kewajiban penyelenggaraan Pemerintahan Desa.

6. Profesionalitas, Profesionalitas adalah asas yang mengutamakan keahlian yang berlandaskan kode etik dan ketentuan peraturan perundangundangan.

7. Akuntabilitas, Akuntabilitas adalah asas yang menentukan bahwa setiap kegiatan dan hasil akhir dari penyelenggaraan Pemerintahan Desa harus dapat dipertanggungjawabkan kepada masyarakat desa sesuai dengan ketentuan peraturan perundang-undangan.

8. Efektivitas dan Efisiensi, Efektivitas asas yang menentukan bahwa setiap kegiatan harus berhasil mencapai tujuan yang diinginkan masyarakat desa. Sedangkan yang dimaksu dengan Efisiensi adalah asas yang menentukan bahwa setiap kegiatan yang dilaksankan harus tepat sesuai dengan rencana dan tujuan.

9. Kearifan Lokal, Kearifan Lokal adalah asas yang menegaskan bahwa didalam penetapan kebijakan harus memperhatikan kebutuhan dan kepentingan masyarakat/

10. Keberagaman, Keberagaman adalah penyelenggaraan Pemerintahan Desa yang tidak boleh mendiskriminasikan kelompok masyarakat tertentu.

11. Partisipatif, Partisipatif adalah penyelenggaraan Pemerintahan Desa yang mengikutsertakan Kelembagaan Desa dan masyarakat Desa.

Kompetensi dari Aparatur Desa merupakan unsur penting dalam pelakasanaan Roda Pemerintahan guna mendapatkan pencapaian dari hasil kinerja yang sesuai dengan Peraturan-Peratuan yang berlaku. Masalah Pemerintah saat ini adalah terbatasnya sumber daya manusia yang berkualitas, ini menjadi suatu fenomena yang sekaligus menjadi masalah utama yang dihadapi dalam Penyelenggaraan Pemerintahan Desa diberbagai daerah di Indonesia. Aparatur Desa adalah semua unsur yang mempunyai peran penting dan terlibat sebagai Penyelenggara Pemerintahan desa seperti :

1) Kepala Desa

Kepala Desa/Desa Adat atau yang disebut dengan nama lain merupakan kepala Pemerintahan Desa/Desa Adat yang memimpin penyelenggaraan Pemerintahan Desa. Kepala Desa/Desa Adat atau yang disebut dengan nama lain mempunyai peran penting dalam kedudukannya sebagai kepanjangan tangan negara yang dekat dengan masyarakat dan sebagai pemimpin masyarakat. Kepala Desa wajib mengangakat Perangkat Desa dan dikonsultasikan kepada Camat atas nama Bupati/Walikota, dan Perangkat terdiri dari sebagai berikut :

\section{Jurnal Sociopolitico}


a. Sekretaris Desa, adalah salah satu perangkat desa yang bertugas mengurus administrasi di desa. Sekretaris desa merupakan Pegawai Negeri Sipil (PNS) yang diangkat oleh Bupati.

b. Pelaksana Teknis, teridiri dari beberapa bagian seperti Kaur Umum, Kaur Pemerintahan, Kaur Keuangan, Kaur Pembangunan dan Kaur Sosial.

c. Pelakasa Kewilayahan, Terdiri dari beberapa bagian seperti Rukun Warga (RW) dan Rukun Tetangga (RT).

Mengingat kedudukan, kewenangan, dan keuangan Desa yang semakin kuat, penyelenggaraan Pemerintahan Desa diharapkan lebih akuntabel yang didukung dengan sistem pengawasan dan keseimbangan antara Pemerintah Desa dan Lembaga Desa, khususnya Badana Permusyawaratan Desa yang dalam kedudukannya yang mempunyai fungsi penting dalam menyiapkan kebijakan Pemerintahan Desa bersama Kepala Desa, harus mempunyai visi dan misi yang sama dengan Kepala Desa sehingga Badan Permusyawaratan Desa tidak dapat menjatuhkan Kepala Desa yang dipilih secara Demokratis oleh Masyarakat.

2) Badan Permusyawaratan Desa

Badan Permusyawaratan Desa atau yang disebut dengan nama lain adalah lembaga yang melakukan fungsi pemerintahan yang anggotanya merupakan wakil dari penduduk Desa berdasarkan keterwakilan wilayah dan ditetapkan secara demokratis. Badan Permusyawatan Desa merupakan badan permusyawaratan ditingkat Desa yang turut membahas dan menyepakati berbagai kebijakan dalam penyelenggaraan Pemerintahan Desa. Dalam upaya meningkatkan kinerja kelembagaan di tingkat Desa, memperkuat kebersamaan, serta meningkatkan partispasi dan pemberdayaan masyarakat, Pemerintah Desa dan/atau Badan Permusyawaratan Desa memfasilitasi penyelenggaraan Musyawarah Desa. Musyawarah Desa atau yang disebut dengan nama lain adalah forum musyawarah antara Badan Permusyawaratan Desa, Pemerintah Desa, dan unsur masyarakat yang diselenggarakan oleh Badan Permusyawaratan Desa untuk memusyawarahkan dan menyepakati hal yang bersifat strategis dalam penyelenggaraan Pemerintahan Desa. Hasil Dusyawarah Desa dalam bentuk kesepakatan yang dituangkan dalam keputusan hasil musyawarah dijadikan dasar oleh Badan Permusyawatan Desa dan Pemerintah Desa dalam menetapkan Kebijakan Pemerintah Desa.

Kompetensi merupakan akumulasi dari kemampuan individu dalam melaksanakan pekerjaannya, yang didalamnya terdapat beberapa unsur, seperti Pengetahuan adalah segenap apa yang kita ketahui tentang suatu objek, sebagian besar pengetahuan manuasia diperoleh melalaui mata dan telinga. Dalam Penyelenggaraan Pemerintah Desa Dalam Penyelenggaraan Pemerintahan Desa terdapat asas-asas yang harus diperhatikan, baik oleh pemerintah maupun oleh masyarakat desa. Hal ini bertujuan agar penyelenggaraan Pemerintahan Desa tidak melenceng dari aturan yang berlaku. Dalam

\section{Jurnal Sociopolitico}


penyelenggaraan Pemerintahan Desa Henda Kompetensi dari Aparatur Desa sudah mumpuni jika diukur dari indikator Pengetahuan dikarenakan Aparatur Desa Henda dalam menyelenggarakan Pemerintahan Desa sangat memperhatikan asas-asas penyelenggaraan Pemerintahan Desa seperti asas kepastian hukum, tertib penyelenggaraan pemerintahan, tertib kepentngan umum, keterbukaan, proporsionalitas, akuntabilitas, efektivitas dan efisiensi, kearifan lokal, keberagaman, dan partisipatif.

Kompetensi sangat berkaitan dengan Pemahaman seseorang dalam melakukan pekerjaannya. Pemahaman merupakan kedalaman kognitif dan afektif yang dimiliki oleh individu merupakan sesuatu hal yang kita pahami dan kita mengerti dengan benar. Terbatasnya Sumber Daya Manusia pada saat ini menjadi suatu permasalahan besar yang dihadapi oleh pemerintah. Aparatur Pemerintah Desa Henda dapat dibilang cukup memahami tugas dan fungsi masing-masing. Hal ini dapat dilihat dari hasil penyelenggaraan Pemerintahan Desa yang dimana desa Henda seperti setiap kegiatan dilaksanakan atas dasar musyawarah desa dimana musyawarah desa adalah hasil keputusan tertinggi yang ada didesa sesuai dengan amanat Undang-Undang dan juga dapat dilihat dari tingkat pencapaian suatu kinerja yaitu mendapatkan penghargaan sebagai Desa Terbaik dari 8 desa. Dalam penyelenggaraan Pemerintahan Desa dilaksanakan sesuai dengan Rencana Kerja Pemerintah Desa (RKPDes), penyelenggaraan Pemerintahan Desa dilaksanakan oleh Aparatur Desa dengan melibatkan masyarakat desa dengan semangat gotong royong.

Dalam

penyelenggaraan Pemerintahan Desa,
Aparatur Desa sebagai penyelenggara rumah tangganya sendiri dan merupakan penanggungjawab utama dibidang pemerintahan, pembangunan, dan kemasyarakatan. Dalam penyelenggaraan Pemerintahan Desa sangat diperlukan Kompetensi dari Aparatur Desa terutama pada sikap dari Aparatur Desa dalam melaksakan tugas dan fungsinya. Sikap yaitu perasaan senang tidak senang, suka tidak suka terhadap sesuatu ransangan dari luar. Sikap menjadi salah satu tolak ukur dalam penyelenggaraan Pemerintahan Desa sehingga hasil yang diharapkan oleh masyarakat dapat sesuai dengan apa yang sudah mereka sampaikan pada musyawarah desa. Sikap dari Aparatur Desa Henda dapat dibilang sudah profesional dikarenakan apabila Aparatur Desa mendapatkan suatu ransangan masalah dari luar tidak pernah berimbas pada pekerjaan yang lainnya.

\section{B. Faktor-Faktor yang Mempengaruhi Kompetensi Aparatur Desa di Desa Henda Kecamatan Jabiren. \\ Dalam pelaksanaan penyelenggaraan} Pemerintahan Desa Henda yang mempengaruhi dalam upaya peningkatan Kompetensi dari Aparatur Desa yaitu Motivasi Kerja. Motivasi perlu ditingkatkan agar kompetensinya juga bisa meningkat. Motivasi Kerja dari Aparatur Desa terutama Badan Permusyarawatan Desa (BPD) yang sebagai mitra kerja dari Pemerintah Desa menurun dikarenakan belum terpenuhinya kebutuhan operasional karena sebenarnya mengikuti seiring dengan apa yang direncanakan. Apabila berbicara masalah motivasi berarti akan bersamaan membahas Kompetensi karena variabel yang sangat berpengaruh bagi Kompetensi ialah motivasi. Motivasi memiliki unsur yang penting dalam pengembangan Kompetensi. 
Permasalahan diatas yang mengakibatkan fungsi yang dimiliki oleh Badan Permusyawaratan Desa adalah legislasi, pengawasan, penyalur aspirasi masyarakat, penyelenggaraan musyawarah desa tidak dijalankan dengan optimal oleh Badan Permusyawaratan Desa. Kurangnya koordinasi dari Aparatur Desa (Pemerintah Desa dan Badan Permusyawaratan Desa) mengakibatkan pengembangan kompetensi melemah kepada satu pihak dan akan menguatkan pengembangan kompetensi kepada satu pihak.

\section{Kesimpulan}

Berdasarkan hasil penelitian Kompetensi Aparatur Desa dalam Penyelenggaraan Pemerintahan Desa di Desa Henda Kecamatan Jabiren Raya Kabupaten Pulang Pisau dapat diambil kesimpulan sebagai berikut :

Aparatur Desa adalah Pemerintah Desa dan Badan Permusyawaratan Desa yang dapat dikatakan sebagai ujung tombak sebagai pelaksana penyelenggaraan Penyelenggaraan Pemerintahan Desa, Kompetensi dari Aparatur Desa di Desa Henda sudah cukup baik karena dalam penyelenggaraan Pemerintahan Desa Aparatur Desa Henda selalu berpegang dan memperhatikan asas-asas penyelenggaraan Pemerintahan Desa. Aparatur Desa Henda juga dalam menyelenggarakan Pemerintahan Desa dilaksanakan atas dasar musyawarah desa dimana musyawarah desa adalah hasil keputusan tertinggi yang ada didesa sesuai dengan amanat UndangUndang. Dalam melakukan penyelenggaraan Pemerintahan Desa Aparatur Desa sudah profesional dikarenakan apabila Aparatur Desa mendapatkan suatu ransangan atau masalah dari luar tidak pernah berimbas pada pekerjaan yang lainnya.
Dalam pelaksanaan penyelenggaraan Pemerintahan Desa di Desa Henda terjadinya Kurangnya kordinasi dari Aparatur Desa (Pemerintah Desa dan Badan Permusyawaratan Desa) mengakibatkan pengembangan Kompetensi lemahnya kepada satu pihak dan akan menguat pengembangan Kompetensi kepada satu pihak. Motivasi Kerja dari Aparatur Desa terutama Badan Permusyarawatan Desa (BPD) yang sebagai mitra kerja dari Pemerintah Desa menurun dikarenakan belum terpenuhinya kebutuhan operasional karena sebenarnya mengikuti seiring dengan apa yang direncanakan. Apabila berbicara masalah motivasi berarti akan bersamaan membahas Kompetensi karena variabel yang sangat berpengaruh bagi Kompetensi ialah motivasi.

\section{Referensi}

Anwas, M Oos. 2014. Pemberdayaan Masyarakat di Era Global. Bandung: Yayasan Penerbit Alfabeta

Boyatzis, RE. 1984. The Competent Manager: A Model for Effective Performance. New York: Jihn Willy $\&$ Sons.

Nurcholis, Hanif. 2011. Pertumbuhan dan Penyelenggaraan Pemerintahan

Desa. Yogyakarta: Erlangga

Pace, R. Wayne dan Don F. Faules. 1993Komunikasi Organisasi:

Strategi Meningkatkan Kinerja Perusahaan. Edisi Indonesia. Bandung: Remaja Rosdakarya.

Satori, Djam'an dan Komariah Aan. 2010. Metodologi Penelitian Kualitatif. Bandung : Alfabeta

Sedarmayanti. 2007.Manajemen Sumber

Daya Manusia.Bandung : PT

RefikaAditama,. 
Sitepu, P. Anthonius. 2012.Teori-teori Politik. Yogyakarta: Graha Ilmu.

Sutrisno, Edy. 2010. Manajemen

Sumber DayaManusia.Jakarta:

Prenada Media Group.

Yamin, Martinis. 2004. Strategi Pembelajaran Berbasis Kompetensi. Jakarta: Gaung Persada Press.

\section{Sumber Lain :}

Undang-Undang No 32 Tahun 2004

Tentang Pemerintahan Daerah

Undang-Undang No 6 Tahun 2014 Tentang Desa

Undang-Undang No 6 Tahun 2014 Tentang Desa (pasal 78-86 tentang Pembangunan Desa dan Pembangunan Kawasan Perdesaan). Permendagri 114 Tahun 2014 Tentang Pedoaman Pembangunan Desa

Peraturan Pemerintah Nomor 43 Tahun 2014 Tentang Peraturan Pelaksanaan Undang-Undang Nomor 6 Tentang Desa 